\title{
Influences on Sponsorship Deals in NASCAR: Indirect Evidence from Time on Camera
}

\author{
by \\ Kurt W. Rotthoff ${ }^{1}$ \\ Assistant Professor \\ Department of Economics and Legal Studies \\ Seton Hall University \\ Craig A. Depken, II \\ Professor \\ Department of Economics \\ University of North Carolina - Charlotte \\ Peter A. Groothuis \\ Professor \\ Department of Economics \\ Appalachian State University
}

\begin{abstract}
:
When corporate sponsors want to maximize their exposure, they often focus sponsorship dollars on events, teams, and athletes that will prove to be reliable, respectable, and, most important, repetitive advertising outlets. Analyzing the factors that increase a broadcaster's propensity to display a sponsor during television broadcasts is often hard to measure. Using a unique data set describing NASCAR broadcasts, we indirectly analyze what influences the value of a sponsorship contract through a proxy for driver sponsorship value: the value of time on camera. We find that the value of time on camera is influenced by driver performance and their celebrity status, as measured by driver experience and inherited brand-name capital. Although the values of individual sponsorship contracts are generally not reported, the evidence herein suggests that driver performance and status likely influence the value of NASCAR sponsorship contracts.
\end{abstract}

KEY WORDS: Sports, Sponsorship, NASCAR, Naming Rights, Return on Investment, Advertising JEL Codes: D23, L14, M31, M37

\footnotetext{
${ }^{1}$ Craig Depken: cdepken@ uncc.edu or 704.687.7484; Peter Groothuis: groothuispa@appstate.edu or 828.262.6077; Kurt W Rotthoff: rotthoff@ gmail.com or 973.761.9102. We appreciate comments received by seminar participants at the 2010 Southern Economic Association annual meetings. Any mistakes are our own.
} 


\section{Introduction}

Broadcasters often have a major influence on the value of marketing strategies. When a broadcaster discusses one athlete, and her sponsors, over another, this has considerable implications on the value of that sponsorship deal (and any future contracts that athlete can sign). Corporations have long dedicated advertising dollars to purchasing naming rights of stadiums and events, official sponsorship of Olympics teams and games, placement of corporate logos on athletes' and teams' jerseys, hats, and equipment, and in hiring athletes as spokespeople for their products. When broadcasters spend more time discussing stadiums, events, or athletes by the sponsor's name, rather than by the name of the athlete, team, or city, the sponsor increases their exposure. Companies are willing to pay for these large sponsorship contracts because they expect to use sponsor mentions as part of their marketing campaign. As such, understanding what gets a sponsor mentioned, and how to get one's sponsor mentioned, increases the value of the sponsorship contract to the athlete or team. In this study, we determine what characteristics influence broadcasters to mention, or show, an athlete's sponsor. Specifically, we focus on what characteristics increase the ability for a sponsored athlete, or team, in NASCAR to be mentioned or shown during nationally televised races.

Unfortunately, the values of NASCAR sponsorship deals are often not announced in detail, leaving considerable ambiguity about what is truly valued by sponsors (and the audience toward which the sponsorship deal is directed). Using a unique data set describing the value of each NASCAR driver's time-on-camera over the course of the race season, we investigate which driver characteristics enhance the value of time-oncamera. Because the broadcasters decide which athletes and teams to discuss and show 
during a race, the characteristics that influence time-on-camera would therefore be valued by the sponsor and help inform about the value of the sponsorship deal itself.

To investigate what causes a driver to be mentioned or seen on air more often during the course of the season, we focus on performance variables, such as laps led and race results, as well as driver attributes. Because the television broadcaster seeks to maximize audience size (ceteris paribus), any differences in time-on-camera not associated with driver performance would ostensibly reflect the preferences (writ large) of the audience, and thus value in the sponsorship contracts.

To the extent that some drivers are more popular than others, independent of ability, economic theory would predict that more popular drivers would try to monetize their popularity through their sponsorship contracts. There are two parts to this monetization process: first is the broadcasters' coverage of the 'fan favorites'. The pressure from the audience to see, and hear about, their favorite drivers influences the time-on-camera for all drivers. The second factor is the popularity that brings in larger advertising contracts off the track. Although this second part is not the focus of this study, we briefly discuss these outside endorsement contracts.

Given that both skill level and popularity vary across drivers, it is valuable to analyze what elements increase the probability that a driver, and thus the sponsors of that driver, is shown and discussed during a race. The International Events Group (IEG) says "[b]illions of dollars worth of spending that formerly went to conventional media will be put behind sponsorship” (IEG Sponsorship Report 2006; commenting about sponsorship spending on the whole). As these sponsorship dollars grow, so does the value of knowing what aspects get sponsors shown. In the next section we discuss the economic, finance, 
and marketing literature. In the third section we provide details on the data. In the fourth section we discuss the value of superstar status in corporate sponsorship, in the fifth section the methodology, and the results in the sixth section. Section seven discusses the value of outside endorsements and the last section concludes with discussion of the value of corporate sponsorship.

\section{The Value of Corporate Sponsorship}

Although the measurement of sponsorship effectiveness if notoriously difficult (for a description of the difficulty see Breuer and Rumpf 2012), the marketing literature, as well as the economics and finance literature, have all attempted to measure the overall benefit and effectiveness of corporate sponsorship dollars. In the finance literature, event studies have found a positive relation between athletic sponsorship and stock prices. Cornwell, Pruitt, and Clark (2005) find that sponsorship in the National Basketball Association (NBA), Major League Baseball (MLB), the National Hockey League (NHL), and the Professional Golfers Association (PGA) all increased the stock prices of the sponsoring firms. Pruitt, Cornwell, and Clark (2004) also find that announcement of sponsorship of a NASCAR team increases the sponsoring company's stock price. Mahar, Paul, and Stone (2005) find that NASCAR sponsors that sell directly to end consumers have a positive relationship between winning and sponsors stock price; however, this does not hold for firms that market to businesses.

Durr, Eaton, and Broker (2009) find that a portfolio of corporations that sponsor NASCAR teams consistently outperforms the risk-adjusted returns of the S\&P 500. They claim that NASCAR sponsorship sends a signal of a firm's financial health. Other event 
studies have also found a relationship between athlete image and stock prices. For instance during the Tiger Woods scandal in 2009, his sports-related sponsors' stock value decreased by over four percent and the stock prices of his top five sponsors fell by two to three percent (Knittel and Stango 2010).

The marketing literature further explores the role of corporate sponsorship in individual purchase decisions. In this literature corporate sponsorship is defined as a firm's provision of assistance, either financial or in-kind, to an activity (e.g., a sporting or musical event, festival, or arts) for achieving commercial objectives (Meenaghan 1991). The marketing literature suggests that the primary objective of sponsorship is to enhance brand loyalty and recognition and ultimately influence purchase decisions (Sirgy et al 2008). Gwinner (1997) suggests corporate dollars are used to transfer the image of the event to the product or the company. Amato, Peters, and Shao (2005) find that selfindentified hardcore and moderate fans of NASCAR are more likely to know about and purchase products from NASCAR sponsors. In addition they find that the decision to support a particular driver is independent of the sponsor but once a fan supports a driver they are more likely to buy the product of the driver's sponsor.

\section{NASCAR Teams, NASCAR Drivers, and Corporate Sponsorship}

Corporate sponsorship has a long history in NASCAR. In 1971 Junior Johnson approached R. J. Reynolds Tobacco Company (RJR) with the idea of sponsoring his race car for the NASCAR circuit. RJR, realizing the attendees of NASCAR races were a desirable demographic for their product, agreed and sponsored his car for approximately $\$ 100,000$. This started the modern era of corporate sponsorship in NASCAR. It was also 
during this time that Ford Motor Co. and General Motors Corp. coined "Win on Sunday;

Sell on Monday" as their advertising catch-phrase. From this point forward corporate sponsorship became an important source of funding NASCAR race teams.

Funding a racing team is a multimillion-dollar undertaking (McGee 2005) and, for a typical NASCAR team, sponsorship contracts are the primary source of its funding (Gage 2006). According to Brown (2008), top NASCAR sponsorship deals are usually around \$20 million per year for the Sprint Cup series, the highest circuit in NASCAR. Thus, knowing what makes a particular driver more popular with the audience, and therefore more valuable to the sponsors, is important for NASCAR teams, NASCAR drivers, and the sponsors themselves. However, the actual values of sponsorship deals are generally not reported and have not been compiled in sufficient numbers to facilitate statistical analysis.

Naturally, during and immediately after a particular race, there is considerable focus on the drivers who contended for winning the race, with the greatest focus often falling on the driver who won or, at times, the driver who came in second place. This suggests that the value of time-on-camera is positively correlated with contending and winning races. ${ }^{2}$ However, Groothuis and Groothuis (2008) suggest that there may be a number of other reasons that a driver is shown on the television broadcast other than their position in the race. One reason is that brand-name capital is established through driver experience. Lou et al (2010) suggest that movie stars create a brand image through

\footnotetext{
${ }^{2}$ Given that sponsors are the primary source of funding of a race team, driver performance might be directly linked to the value of the sponsorship deal because the quality of the car depends upon the resources available to the race team. The reverse causality of largest sponsorship contract leading to the best driver due to the best car is observationally equivalent to best driver land the highest contract. Our analysis focuses on performance on the track, either due to the driver or the car, leading to time on camera or is it due to some other reason.
} 
sequential movie releases that enhances their brand equity. In addition they find that outside activities may enhance or distract from celebrity. Similarly, in NASCAR, past experience may create driver brand-name capital that is reflected in fan popularity. This popularity may then manifest itself as a preference for seeing that driver during the race regardless of the driver's running position.

While driver name-brand capital might be generated by the driver's own actions, it is also possible that part of a driver's name-brand capital is inherited from previous drivers within the same family, i.e., fathers, grandfathers, uncles, and brothers. ${ }^{3}$ This occurs when a driver's name becomes its own brand, e.g., Earnhardt, Petty, or Busch. ${ }^{4}$ The empirical analysis also tests for whether driver name-brand capital is reflected in the value of time-on-camera and, by extension, is valuable to sponsors. Given the difficulty in obtaining data concerning sponsorship deals, the use of a proxy for sponsorship value is a second-best option that nevertheless can help shed light on what broadcasters think is valuable to fans and, by extension, valuable to sponsors as well. In this study we use the value of time-on-camera as such a proxy. The Value of Time-On-Camera (VTOC) is the monetized value of television exposure (in dollar terms) and is calculated by the consulting firm Joyce Julius. ${ }^{5}$ To make these calculations the firm takes the amount of time a brand is visually 'clear and in-focus' during the broadcast of the race, and add the

\footnotetext{
${ }^{3}$ This comes from Laband and Lentz's (1985, 1990a, 1990b) work finding that occupational following is an efficient mechanism for the transfer of rents across generation, especially when the family name has goodwill attached to it.

${ }^{4}$ For those not familiar with these last names, Dale Earnhardt, Jr. is the son of the late Dale Earnhardt, who died on the last lap of the 2001 Daytona Five Hundred, and is the most popular driver in NASCAR. The Petty name has been associated with NASCAR since Lee Petty started racing in 1949; in 2008 Kyle Petty was the last Petty to race in NASCAR's premier circuit. Kyle Busch and Kurt Busch are brothers who race in NASCAR's premier circuit; Kurt was the 2004 champion of the NASCAR Sprint Cup and Kyle is a controversial but high quality driver. Potential selectivity bias might exist because we do not have data on sons of former drivers who do not make the NASCAR series.

${ }^{5}$ Joyce Julius \& Associates, Inc founded in 1985 measures sponsorship impact in media. The website for this company is http://www.joycejulius.com/index.html .
} 
verbal brand mentions throughout the race (with each brand mention being equal to ten seconds of clear and in-focus visual exposure). The overall time of brand exposure is then multiplied by the non-discounted cost of a commercial airing during that specific race yielding the VTOC for each driver. ${ }^{6}$ The VTOC is calculated for each driver-race outcome and then aggregated to the season's total VTOC for each driver. These data are matched to each driver's season-level performance and personal characteristics for each season they race in the top NASCAR series.

From the 2001 through the 2007 season, twelve drivers had VTOC values of more than $\$ 100$ million per season; these drivers are reported in Table 1. During the sample period, Dale Earnhardt Jr. has the highest VTOC of all drivers each season, with a maximum VTOC of approximately $\$ 190$ million in $2003 .^{7}$ The mean VTOC of all drivers is $\$ 38.6$ million dollars while the median VTOC is $\$ 26$ million dollars; thus the distribution of VTOC values is skewed toward superstars. The twelve drivers listed in Table 1 are clearly in the right tail of a skewed distribution of VTOC; each has a value that is at least two standard deviations above the mean. Therefore, as the VTOC is skewed it is anticipated that the value of sponsorships is also skewed toward superstars.

\footnotetext{
${ }^{6}$ The VTOC is defined by Joyce Julius as:

"All clear and in-focus exposure time a brand receives during the broadcast. In order for the brand's logo to be considered clear and in-focus, the image must not be blurred or obstructed in a way as to prevent the typical viewer from acknowledging the brand. Along with the visual exposure, Joyce Julius also monitors each verbal mention received by the brand throughout the telecast. Mentions are valued at ten seconds each, based on an average of 3 brand mentions per 30second commercial. Once all of the visual and/or verbal exposure has been tabulated, a value for the brand's exposure is calculated by comparing the on-screen time and mentions to the nondiscounted cost of a commercial, which ran during the specific program in question" (Joyce Julius and Associates).
}

\footnotetext{
${ }^{7}$ Dale Jr. has the highest VTOC in our sample and is often voted as the 'fan favorite' in those seasons. For that reason the use of a fan favorite proxy would be the same as having a Dale Jr. dummy variable. We have chosen to use a Dale Jr. dummy in one specification, instead of a fan favorite measure, knowing the outcome is the same.
} 
[Table 1]

\section{The Value of Superstars in Corporate Sponsorship}

As broadcasters make the decision of who to air and discuss in NASCAR events it is essential to understand the different reasons drivers and their cars are discussed and shown. Superstar drivers are shown and discussed at a much higher rate, independent of their current position in a given race, than their counterparts. Thus, being a superstar increases the value of a sponsorship deal, even if that superstar is underperforming in race production.

Because small differences in talent can translate into large differences in earnings (Adler 1985), the ability to separate the superstars from the pack is highly valued. Yet, determining the differences that separate superstar talent has proven difficult (Kruger 2005). Knowing that multiple mediocre performances do not add up to the quality found in one great performance (Rosen 1981) magnifies the importance of finding these superstars. Hamlen $(1991,1994)$ and Kruger (2005) analyze this in vocal musical talent and Franck and Nüesch (2010) analyze both talent and popularity in German soccer to see what it takes to be a superstar. Our data provide a unique opportunity to study the value of both performance and celebrity on superstar status by analyzing NASCAR drivers.

\section{Methodology}

The data used here describe all Sprint Cup (formally Winston Cup) drivers from 2000-2007. Descriptive statistics are reported in Table 2. The VTOC of all drivers averaged $\$ 38.6 \mathrm{~m}$ during the sample period, with a minimum of $\$ 17,500$ and a maximum 
of approximately $\$ 190$ million. Driver skill or performance is measured in a number of ways. An obvious performance measure is how many races the driver won over the course of the season. To accurately measure the impact of driver wins we include a measure for the number of wins of the current season (wins) and, in a separate regression, add to that a measure for the number of wins in the previous season ( wins $\left._{t-1}\right)$. The average number of wins across all drivers in a given season is approximately one, but there are a large number of drivers who never win a race and several drivers who win multiple races in a given season, e.g., Jimmie Johnson won ten races in 2007. Because contending for a race win is often an important contribution to the drama of the television broadcast, we identify the number of times each driver finished in the second through fifth (Finish 2-5) and sixth through tenth (Finish 6-10) positions over the course of the season.

[Table 2]

Other performance measures that impact the amount of broadcast time a driver receives is the number of times a driver did not finish a race (DNF). There are two ways to receive a DNF: DNFs caused by a crash (Crash) and those caused by mechanical failure $(D N F)$. Across all drivers, the average number of DNFs was approximately five with less than three being caused by wrecks. We distinguish between the two types of DNFs because they might have different impacts on a driver's VTOC. Wrecks are often replayed during and after a race broadcast and therefore might increase the VTOC relative to mechanical failures, after which a car is taken off the track but with no compelling reason to replay the mechanical failure. Thus, it is anticipated that DNFs caused by wrecks increase VTOC relative to DNFs caused by mechanical failure. We also control for the total number of races in which each driver participated during the 
course of the season (Races) and, in the same regression, the total laps led during the course of the season (Laps Led). ${ }^{8}$

It is anticipated that the number of races in which a driver participates increases VTOC. The average driver started approximately 33 of the 36 races in a given season, although there are a large number of drivers who participate in every race and several who participate in only a few races (minimum of four). Does a driver have to win to get a high VTOC; or does leading laps have a similar impact? Given our unique data, we have the ability to separately identify these impacts. We run multiple models, both without laps led and with laps led, separating these impacts. We posit that more laps led during the course of a season increases the driver's VTOC, ceteris paribus. The average driver led just over 270 laps during the season although there are many drivers who led considerably fewer laps and many who led considerably more. We also run these models with and without lagged number of wins from the previous season for each driver.

However, as postulated above, VTOC might not be determined by driver performance alone. As witnessed by the high VTOC value for Dale Earnhardt, Jr., there might be additional factors such as popularity that contribute to a driver's VTOC value and thus to the driver's ability to extract greater sponsorship fees. We use the number of years racing in NASCAR's premier circuit as a proxy for driver's popularity. This proxy works well because drivers are creating their own brand name on the track throughout their years of service and more popular drivers will retain contracts longer than less popular drivers (controlling for skill). Also, while there are rankings of the most popular drivers during our sample period, unfortunately Dale Earnhardt Jr. is voted the most

\footnotetext{
${ }^{8}$ While the most famous drivers in NASCAR's Sprint Cup Series generally drive every race several drivers attempt but do not qualify for each race.
} 
popular driver every year of the sample, making it an unusable statistic. While drivers develop their brand name through their own driving, it is possible for a driver to inherit brand name capital through familial connections within the sport of NASCAR. This establishes a proxy for last (brand)-name recognition which is a form of popularity with the NASCAR audience.

We estimate the impact of skill and popularity on VTOC using the following empirical model:

$$
\begin{aligned}
& \text { Value }_{i t}=\beta_{0}+\beta_{1} \text { Win }_{i t}+\beta_{2}(\text { Finish } 2-5)_{i t}+\beta_{3}\left(\text { Finish }_{6-10}\right)_{i t}+\beta_{4} D N F_{i t}+ \\
& \beta_{5} \text { Crash }_{i t}+\beta_{6} \text { Races }_{i t}+\beta_{7} \text { Laps Led }_{i t}+\gamma X_{i t}+\theta N_{i t}+\varphi \text { Year }_{i t}+\varepsilon_{i t}
\end{aligned}
$$

where the $\beta$ 's are parameters to be estimated and $\varepsilon$ is a zero-mean error term. The dependent variable, Value, is measured in both the linear and natural log forms of the VTOC for each driver $i$ in year $t$. The natural $\log$ form controls for the skewed nature of the data. The $X$ vector includes driver experience and experience squared, to control for any non-linearity, and, following Groothuis and Groothuis (2008), the $N$ vector contains variables describing familial connections of driver $i$ to other NASCAR drivers. The vector Year contains dummy variables for the various years in the sample to control for any secular changes in VTOC values.

In addition to the two models described in equation 3, we also estimate equation 4 with and without laps led:

$$
\begin{aligned}
& \text { Value }_{i t}=\beta_{0}+\beta_{1} \text { Win }_{i t}+\beta_{2} \text { Win }_{i(t-1)}+\beta_{3}(\text { Finish } 2-5)_{i t}+\beta_{4}(\text { Finish 6-10) })_{i t} \\
& +\beta_{5} D N F_{i t}+\beta_{6} \text { Crash }_{i t}+\beta_{7} \text { Races }_{i t}+\beta_{8} \text { Laps Led }_{i t}+\gamma X_{i t}+\theta N_{i t}+\varphi \text { Year }_{i t}+\varepsilon_{i t} .
\end{aligned}
$$


While the lagged number of wins limits our data to only drivers who have competed more than one year, including the variable reveals any carry-over value of winning races in the previous season. This regression decreases the number of observations employed in the regression, but continues to support our findings of the broadcaster's impact on VTOC.

\section{Empirical Results}

In Table 3, we report the results of the empirical model described in the previous section (equation 3). Model 1 excludes total laps led whereas Model 2 includes it; Model 3, without laps led, and Model 4, with laps led, use the natural log of VTOC as the dependent variable. In Model 1, we find that winning a race leads to an economically and statistically meaningful increase in the VTOC; winning yields approximately $\$ 6.31$ million in VTOC on average. Finishing second through fifth provides $\$ 2.51$ million in value and finishing sixth through tenth provides $\$ 1.65$ million dollars of value; both of these parameters are also statistically significant. These results follow a tournament payment structure. We also find that experience increases the VTOC but at a decreasing rate. When using the natural log of VTOC, in Model 3, winning causes a driver' VTOC to increase by an economically and statistically meaningful 12 percent. Finishing second through fifth and sixth through tenth also matter, but the tournament structure does not hold for this specification; finishing sixth through tenth has a larger coefficient than finishing second through fifth, although they are not statistically different from each other. 
Surprisingly, in the linear model, neither the total non-crash DNFs nor the crashrelated DNFs influence the VTOC, although in the log-linear model the parameter on non-crash DNFs is negative and significant. The non-crash DNF is statistically different from the crash DNF, so although a driver seems to get no VTOC benefit from crashing, they do receive a lower VTOC from exiting the race early without wrecking.

\section{[Table 3]}

Models 2 and 4 in Table 3 add controls for the total laps led. In these models, the vast majority of the parameter estimates do not change in magnitude or statistical significance. However, in these models the influence of finishing first on VTOC is now clearer. It is not the victory itself that drives the increase in the VTOC, rather it is leading laps during the race. Indeed, if a driver were to win on the last lap having led no laps, the impact of the victory on VTOC is relatively minor. On the other hand, most race winners lead a number of laps and therefore enjoy a boost in VTOC through the mechanism of leading laps.

Throughout the race the broadcaster commentary is generally focused on the various drivers, their cars, and pit crews, and the strategies each might employ to increase their odds of winning. While broadcasters generally make two or three "sweeps" throughout the entire field, starting with the leader and ending with the last car, generally the broadcaster focus on the strategies of the cars and drivers in the top ten spots and discuss what those drivers need to do to finish in the top spot. Thus, it is not the victory in-and-of itself that matters. In Models 2 and 4, finishing second through fifth and finishing sixth through tenth are both statistically significant and positively correlated with VTOC. 
The total number of laps led is positively related to the VTOC, as expected; for each lap led the VTOC increased by $\$ 27,120$ or .05 percent. Driver experience continues to have a positive influence on the VTOC; for every year of experience the driver's VTOC increases by $\$ 1.7$ million, although at a decreasing rate. Using the first specification, we find that the average driver who moves from 4 to 5 years of experience would enjoy an increase in VTOC of approximately $\$ 920,000$, whereas the average driver who moves from 10 to 11 years of experience would enjoy an increase of approximately $\$ 207,000$. When using the natural log of VTOC, Model 4 , the experience and experience squared terms are jointly significant.

The evidence in all four models support the findings of Groothuis and Groothuis (2008), name-brand capital seems to transfer within a family. Being the son of a former driver increases a driver's season-long VTOC by $\$ 30.9$ million while being a brother of another NASCAR driver is found to have an insignificant impact on the VTOC.

It is also possible that the VTOC is partly driven by the broadcaster's discussion of the past winners. In Models 5-8 in Table 4, we control for the number of wins a driver had in the previous season. The most notable results are that neither laps led nor finishing first matter in these specifications, however it matters if you have won in the past. There are two possible explanations for this outcome: the broadcasters discuss the past winners and their strategies or past winning is highly correlated with leading laps and winning current races, leading to an issue of multicollinearity. ${ }^{9}$

[Table 4]

\footnotetext{
${ }^{9}$ Hood (2012) argues that consistency, that is, winning is more likely today because of winning yesterday, is not supported in NASCAR Sprint Cup series. This would suggest that broadcasters show previous winners because of fan preference not because they have a higher probability of winning a particular race.
} 
When including the number of wins from the previous season non-crash DNFs continue to decrease VTOC, experience increases VTOC at a decreasing rate, and being the son of a driver increases VTOC.

While there is a strong influence of being the son of a former (or current) NASCAR driver on a driver's VTOC, this result might be driven by only one or two individual drivers. As shown in Table 1, Dale Earnhardt Jr. had the highest VTOC during each of the seven years of the sample and is the son of the late Dale Earnhardt Sr., who lost his life in a crash during the last lap of the 2001 Daytona 500. Dale Earnhardt Sr., nicknamed "The Intimidator," was among the five first inductees to the NASCAR Hall of Fame, won seven championships and seventy-six races, and was one of the most popular drivers in the sport. Dale Sr.'s brand-name capital is clearly a potential contributing factor to his son's popularity, which introduces the possibility that the findings in Tables 3 and 4 are not externally valid. ${ }^{10}$ To test whether this is the case, in Table 5 we independently control for each driver who is a son of a previous NASCAR driver.

[Table 5]

When controlling for each son individually, winning races becomes significant when controlling for laps led, which also remains significant. However, this impact again goes away when controlling for the previous season's wins. Finishing second through fifth and sixth through tenth are also positively related to VTOC. The parameters on the number of non-crash related DNFs continues to be negative and significant, with no impact on VTOC when a DNF occurs because of a crash. When controlling for past wins, experience has a jointly significant impact on the VTOC, increasing at a declining rate.

\footnotetext{
${ }^{10}$ Dale Earnhardt, Jr. has won a total of 19 NASCAR Sprint Cup Series races in his career but only three races from 2005 through 2011 season. Nevertheless, he remains one of the most popular drivers in the circuit.
} 
Of the sons in the sample analyzed here, only Dale Earnhardt Jr., Dale Jarrett (whose father was former NASCAR champion Ned Jarrett), and Johnny Benson Jr., received a positive and statistically significant increase in their VTOC; all other sons in the sample received no significant change in their VTOC based on their name-brand capital. Given the large values on the two 'Dales', our results suggest that brand name capital does not transfer except when their father is a superstar driver.

In table six, we exploit the panel aspect of our data to focus only on the role of performance by controlling for driver specific fixed effects. When using this model, we find that performance matters; the parameters on the number of wins, number of second through fifth, and the number of sixth through tenth finishes are all positive and statistically significant with roughly the same magnitude. We also find that when including laps led, wins are statistically insignificant. We also find that in the fixed effect model experience does not play an important role in determining time on camera. When focusing on the overall variation explained by the model, we find that the between $\mathrm{R}^{2}$ is about .34 and the within $\mathrm{R}^{2}$ is about .32 suggesting that control variables explain about one third of the variation and driver fixed effects explain about one third of the variation. The surprising result is that the overall $\mathrm{R}^{2}$ is .35 suggesting that the performance is a key factor in determining time on camera. We come to this conclusion because the fixed effect controls for driver specific characteristics of both celebrity and ability and these fixed effects explain the same variation as do our explanatory variables on driver performance. These results suggest that performance of the drivers plays a major role but driver specific aspect plays a minor role.

[Table 6] 


\section{Outside Endorsements}

The results of the previous section suggest that performance, experience, and brand name capital can influence a driver's VTOC. One question that arises from the previous section is: Does sponsorship in a NASCAR race follow the same pattern as sponsors who directly pay athletes to endorse their product? To answer this question we use data from multiple sports. The question we address in this section is: What determines sponsorship contracts for athletes in general? We find that performance plays a major role, while brand name capital and experience play minor roles in determining the value of sponsorship deals athletes can negotiate.

Using data from Sports Illustrated fortunate 50 list on the highest paid athletes in the U.S. from 2007-2012, we focus only on athletes with outside sponsorship deals of more than ten million annually. We find that the largest sponsorship contracts come from five different sports. We find that four drivers from NASCAR, three quarterbacks from the NFL, four professional golfers, nine basketball players in the NBA, and one baseball player in MLB making the list. In general, we find that the athletes on this list tend to be the best in their sports, endorsements tend to rise with years of experience, and that celebrity plays some role.

Focusing first on NASCAR, we find that the four drivers on the list are Dale Earnhardt Jr., Jimmy Johnson, Jeff Gordon, and Tony Stewart; with both Dale Earnhardt Jr. and Jeff Gordon making more than $\$ 10$ million in all six years. We find that Jimmy Johnson makes over $\$ 10$ million the last three years and Tony Stewart makes over $\$ 10$ million in 2012. For all NASCAR drivers, endorsements are increasing over time. When it comes to performance, three of the drivers have won NASCAR champions with Jeff 
Gordon winning four championships, the last in 2001, Jimmy Johnson winning five championships in a row from 2006-2010, and Tony Stewart winning in 2011. Although Dale Earnhardt Jr. has never won the championship his father won it seven times. The results of the outside sponsorship are consistent with the VTOC during races with these four drivers occupying 15 of the 24 spots in Table 2 including the top 11 spots. This implies the VTOC during a NASCAR race is not different than contracting an athlete directly to sponsor a product.

Generalizing determinates of sponsorship contracts in other sports, we find that four golfers, Tiger Woods, Phil Mickelson, Jim Furyk and Michelle Wie, made the list of athletes with endorsements of $\$ 10$ million a year or more. Tiger Woods by far has the largest amount of outside endorsements of any athlete ranging from \$105 million in 2008 to $\$ 54$ million in 2012. During his career Tiger Woods has been the dominate golfer winning 14 major tournaments and being the PGA player of the year ten times in his 16 year career. One thing that is inconsistent with his endorsement contracts compared to other athletes is that his endorsement contracts have been falling with experience rather than increasing. This is most likely due to his marital infidelities, brought to the public eye in 2009, that have damaged his brand name capital. This is consistent with Lou, et al. (2010) who find that movie star brand name capital can fall with celebrity malfeasance.

Phil Mickelson makes the list all six years increasing from $\$ 47$ to $\$ 57$ million in 2012. Mickelson also is a top golfer having won four major tournaments and won the PGA championship in 2005. The third golfer, Jim Furyk, making the list in two years is also a top golfer. He has won one major and was named player of the year once. Michelle Wie is the only women on the list making over $\$ 10$ million in endorsements. She earned 
this in 2007, her second year as a professional golfer and before she made the LPGA tour. Her earnings in 2007 seem to be more from her celebrity status and expected performance, rather than from her actual performance.

The NBA has the most players on the list with nine. Three players make the list all six years: Kobe Bryant, Lebron James, and Dwayne Wade. All three players are considered superstars. Kobe Bryant has won five championships, has been named MVP of the league once, and MVP of the NBA finals twice. Lebron James has won one championship, has been named MVP of the league three times, and MVP of the NBA finals once. Dwyane Wade has won two championships and has been named MVP of the finals once. Shaquille O'Neal made the list only three of the six years because he retired in 2011. In his career he won four championships, was MVP of the league once, and MVP of the finals three times. The other NBA players on the list are all stars, although some are just starting their careers. Kevin Durant is a good example. His $\$ 21$ million in endorsements in 2008 was primarily from Nike during his rookie season.

The three NFL football players on the list are all quarterbacks: Payton Manning, Eli Manning, and Tom Brady. Payton Manning makes the list all six years with over $\$ 10$ million in endorsements. Tom Brady makes the list five years with over $\$ 10$ million and one year with just under $\$ 10$ million. Eli Manning makes only one year with over $\$ 10$ million. It is interesting that Eli and Payton are brothers who are both sons of former NFL quarterback Archie Manning, suggesting that brand name capital might also translate in other sports. Eli and Payton, however, are both stars themselves. Payton Manning has won one super bowl where he was the MVP and was player of the year six times in the AFC. Eli Manning has won two super bowls where he was MVP both times and made the 
list after his second super bowl win. Tom Brady is also a star quarterback winning the super bowl three times and being the MVP of the super bowl twice. He was also named MVP of the NFL twice by the Associated Press.

Derek Jeter is the only MLB baseball player to make over $\$ 10$ million in endorsements in a given year. In 2007 he made $\$ 7$ million in endorsements that had grown to $\$ 12$ million by 2012 . He made over $\$ 10$ million three times. Derek Jeter is a super star in his sport with his team winning the World Series five times; in addition he has been awarded five golden glove awards, one MVP of the World Series, and four silver slugger awards. He is also the Yankees team captain and has been named to the All Star team thirteen times in his seventeen year career.

The results from the "Sports Illustrated Fortunate 50" show that most of the athletes on the list are superstars in their sport. Sponsors value superstar status more than celebrity. Yet celebrity plays a role with some athletes making more in endorsements than their performance suggests. Coupling the results from NASCAR and other sports show that performance enhances the value firms place on athletes who endorse products. As Gwinner (1997) suggests, corporate dollars are used to transfer the image of the event to the product or the company. Firms may then choose super star athletes to transfer their winning image to the product endorsed. 


\section{Conclusion}

When corporate sponsors want to maximize their exposure, they often focus sponsorship dollars on events, teams, and athletes that will prove to be reliable, respectable, and, most important, repetitive advertising outlets. However, what attributes of athletes are desirable to the audience and therefore are of value to potential sponsors? Using a unique dataset describing the value of time on camera in NASCAR's premier circuit, the Sprint Cup, we are able to analyze what factors increase a broadcaster's propensity to display, and discuss, a driver and their sponsor during the television broadcast. Thus, implicitly, what factors increase the value of the driver to the sponsor. Given the competitive nature of the sponsorship market, the attributes that are valuable to the audience, and thus to sponsors, are exactly those attributes drivers would use to increase sponsorship value.

In many sports the primary focus is on winning the season-long championship, which is, in turn, highly correlated with winning percentage over the course of the season. In NASCAR winning is not necessarily everything. While, on average, winning a race will contribute to a driver's value of time on camera, other driver attributes matter as much, if not more. The evidence suggests that leading laps, past wins, past experience, finishing races, and being a son of a previous driver, all contribute to a driver's value of time on camera. We find that both performance and celebrity, based on past experience, are important. Drivers develop a brand-name.

However, the ability to transfer family name-brand capital from one generation to another is not automatic. In our sample we find that only Dale Earnhardt Jr. and Dale Jarrett were able to monetize their family-name brand capital in the form of additional 
value of time on camera, above and beyond their performance statistics. This suggests that sponsors value these drivers more because of the inherited brand name they received from their family name. The value of having a superstar parent lead you in your field is clear in this data. Continued research on what adds value to corporate sponsorship is encouraged. 
Table 1: Drivers with Season-long Value of Time on Camera Greater than \$100 million (2000-2007)

\begin{tabular}{|c|c|c|}
\hline Driver & Value & Year \\
\hline Dale Earnhardt Jr. & $\$ 189,946,510$ & 2003 \\
\hline Dale Earnhardt Jr. & $\$ 183,895,715$ & 2004 \\
\hline Dale Earnhardt Jr. & $\$ 183,069,490$ & 2006 \\
\hline Dale Earnhardt Jr. & $\$ 178,173,950$ & 2007 \\
\hline Dale Earnhardt Jr. & $\$ 166,404,630$ & 2002 \\
\hline Dale Earnhardt Jr. & $\$ 165,594,185$ & 2001 \\
\hline Jimmie Johnson & $\$ 164,078,100$ & 2007 \\
\hline Dale Earnhardt Jr. & $\$ 148,959,580$ & 2005 \\
\hline Jimmie Johnson & $\$ 143,620,695$ & 2006 \\
\hline Jimmie Johnson & $\$ 140,236,910$ & 2005 \\
\hline Jeff Gordon & $\$ 136,437,390$ & 2001 \\
\hline Kevin Harvick & $\$ 130,991,580$ & 2007 \\
\hline Tony Stewart & $\$ 125,006,350$ & 2005 \\
\hline Jeff Gordon & $\$ 122,727,500$ & 2007 \\
\hline Jimmie Johnson & $\$ 121,885,155$ & 2004 \\
\hline Jeff Burton & $\$ 116,577,900$ & 2006 \\
\hline Jeff Burton & $\$ 105,781,765$ & 2007 \\
\hline Michael Waltrip & $\$ 105,483,020$ & 2005 \\
\hline Ricky Rudd & $\$ 105,399,625$ & 2001 \\
\hline Dale Jarrett & $\$ 105,108,475$ & 2001 \\
\hline Tony Stewart & $\$ 104,221,200$ & 2007 \\
\hline Greg Biffle & $\$ 103,124,440$ & 2006 \\
\hline Rusty Wallace & $\$ 102,496,005$ & 2001 \\
\hline Greg Biffle & $\$ 100,440,115$ & 2005 \\
\hline
\end{tabular}


Table 2: Summary Statistics of Data Used in the Study

\begin{tabular}{|c|c|c|c|c|}
\hline \multicolumn{5}{|c|}{ Summary Statistics } \\
\hline Variable & Mean & Std. Dev. & Min & Max \\
\hline Value & $3.87 \mathrm{E}+07$ & $3.71 \mathrm{E}+07$ & $1.75 \mathrm{E}+04$ & $1.90 \mathrm{E}+08$ \\
\hline Total Finish 1 & 0.927632 & 1.596622 & 0 & 10 \\
\hline Total Finish 2-5 & 4.490132 & 4.98048 & 0 & 20 \\
\hline Total Finish 6-10 & 4.391447 & 3.408598 & 0 & 15 \\
\hline Total Finish Other & 23.07895 & 8.130557 & 1 & 36 \\
\hline Total DNF Non-Crash & 2.184211 & 1.936009 & 0 & 15 \\
\hline Total DNF Crash & 2.710526 & 1.862011 & 0 & 9 \\
\hline Total Laps Led & 272.4704 & 378.9457 & 0 & 2320 \\
\hline Experience & 10.97039 & 8.363983 & 1 & 33 \\
\hline Son & 0.125 & 0.331264 & 0 & 1 \\
\hline Brother & 0.259868 & 0.439285 & 0 & 1 \\
\hline
\end{tabular}

$\mathrm{N}=304$ 
Table 3: Determinants of Value of Time on Camera

\begin{tabular}{|c|c|c|c|c|}
\hline VARIABLES & $\begin{array}{l}\text { Model 1: } \\
\text { Value }\end{array}$ & $\begin{array}{l}\text { Model 2: } \\
\text { Value }\end{array}$ & $\begin{array}{l}\text { Model 3: } \\
\text { LnValue }\end{array}$ & $\begin{array}{l}\text { Model 4: } \\
\text { LnValue }\end{array}$ \\
\hline Total Finish 1 & $\begin{array}{c}6.31446 \mathrm{e}+06^{* * *} \\
(0.000)\end{array}$ & $\begin{array}{c}2.85594 \mathrm{e}+06 \\
(0.239)\end{array}$ & $\begin{array}{c}0.11654^{* * *} \\
(0.000)\end{array}$ & $\begin{array}{c}0.05413 \\
(0.148)\end{array}$ \\
\hline Total Finish 2-5 & $\begin{array}{c}2.50767 \mathrm{e}+06^{\star \star \star} \\
(0.000)\end{array}$ & $\begin{array}{c}1.74909 \mathrm{e}+06^{\star \star \star} \\
(0.002)\end{array}$ & $\begin{array}{c}0.08466^{\star \star \star} \\
(0.000)\end{array}$ & $\begin{array}{c}0.07098^{\star * \star} \\
(0.000)\end{array}$ \\
\hline Total Finish 6-10 & $\begin{array}{c}1.65117 \mathrm{e}+06^{* * *} \\
(0.002)\end{array}$ & $\begin{array}{c}1.42982 \mathrm{e}+06^{* * *} \\
(0.006)\end{array}$ & $\begin{array}{c}0.10230^{* * *} \\
(0.000)\end{array}$ & $\begin{array}{c}0.09830^{* * *} \\
(0.000)\end{array}$ \\
\hline Other Finish & $\begin{array}{c}200426.66376 \\
(0.280)\end{array}$ & $\begin{array}{c}230837.38233 \\
(0.211)\end{array}$ & $\begin{array}{c}0.02176^{* *} \\
(0.042)\end{array}$ & $\begin{array}{c}0.02231^{* *} \\
(0.037)\end{array}$ \\
\hline Total DNF Non-Crash & $\begin{array}{c}-9.94445 e+05 \\
(0.196)\end{array}$ & $\begin{array}{c}-1.11156 \mathrm{e}+06 \\
(0.133)\end{array}$ & $\begin{array}{c}-0.06070^{* *} \\
(0.012)\end{array}$ & $\begin{array}{c}-0.06281^{* * *} \\
(0.008)\end{array}$ \\
\hline Total DNF Crash & $\begin{array}{c}425041.86624 \\
(0.623)\end{array}$ & $\begin{array}{c}360326.26708 \\
(0.679)\end{array}$ & $\begin{array}{c}0.02139 \\
(0.475) \\
\end{array}$ & $\begin{array}{c}0.02023 \\
(0.501) \\
\end{array}$ \\
\hline Total Laps Led & & $\begin{array}{c}27,120.22180^{* * *} \\
(0.009)\end{array}$ & & $\begin{array}{c}0.00049^{* * *} \\
(0.006)\end{array}$ \\
\hline Experience & $\begin{array}{c}1.70536 \mathrm{e}+06^{\star * *} \\
(0.008)\end{array}$ & $\begin{array}{c}1.65374 \mathrm{e}+06^{* * *} \\
(0.010)\end{array}$ & $\begin{array}{c}0.02314 \\
(0.363) \\
\end{array}$ & $\begin{array}{c}0.02221 \\
(0.383) \\
\end{array}$ \\
\hline Experience Squared & $\begin{array}{c}-71350.99206^{\star * *} \\
(0.001)\end{array}$ & $\begin{array}{c}-69328.08875^{\star * *} \\
(0.001)\end{array}$ & $\begin{array}{c}-0.00115 \\
(0.163)\end{array}$ & $\begin{array}{c}-0.00111 \\
(0.177) \\
\end{array}$ \\
\hline Son & $\begin{array}{c}3.08629 e+07^{* * *} \\
(0.000)\end{array}$ & $\begin{array}{c}3.14360 \mathrm{e}+07^{\star \star \star} \\
(0.000)\end{array}$ & $\begin{array}{c}0.54021^{\star * *} \\
(0.000)\end{array}$ & $\begin{array}{c}0.55055^{\star \star \star} \\
(0.000)\end{array}$ \\
\hline Brother & $\begin{array}{c}2.23585 \mathrm{e}+06 \\
(0.522)\end{array}$ & $\begin{array}{c}2.49371 \mathrm{e}+06 \\
(0.466)\end{array}$ & $\begin{array}{c}0.09085 \\
(0.412)\end{array}$ & $\begin{array}{c}0.09550 \\
(0.384) \\
\end{array}$ \\
\hline Year Fixed Effects & Yes & Yes & Yes & Yes \\
\hline Constant & $\begin{array}{c}-1.74198 \mathrm{e}+07^{* *} \\
(0.030)\end{array}$ & $\begin{array}{c}-1.77332 \mathrm{e}+07^{\star \star} \\
(0.024)\end{array}$ & $\begin{array}{c}14.95747^{\star * *} \\
(0.000)\end{array}$ & $\begin{array}{c}14.95182^{* * *} \\
(0.000)\end{array}$ \\
\hline H0: Homoscedasticity & $99.74^{\star \star \star}$ & $92.52^{\star \star \star}$ & $39.77^{\star \star \star}$ & $42.72^{\star \star \star}$ \\
\hline Observations & 304 & 304 & 304 & 304 \\
\hline R-squared & 0.555 & 0.572 & 0.520 & 0.526 \\
\hline \multicolumn{5}{|c|}{$\begin{array}{l}\text { Robust pval in parentheses. Test for heteroscedasticity is a Cook-Weisberg test distributed } \\
\qquad \text { Chi-squared with one degree of freedom. } \\
\qquad{ }^{* * *} p<0.01^{* *} p<0.05^{*} p<0.1\end{array}$} \\
\hline
\end{tabular}


Table 4: Determinants of Value of Time on Camera with Wins Lagged One Season

\begin{tabular}{|c|c|c|c|c|}
\hline VARIABLES & $\begin{array}{l}\text { Model 5: } \\
\text { Value }\end{array}$ & $\begin{array}{l}\text { Model 6: } \\
\text { Value }\end{array}$ & $\begin{array}{l}\text { Model 7: } \\
\text { LnValue }\end{array}$ & $\begin{array}{l}\text { Model 8: } \\
\text { LnValue }\end{array}$ \\
\hline Total Finish 1 & $\begin{array}{c}5.25067 \mathrm{e}+06^{* * *} \\
(0.007)\end{array}$ & $\begin{array}{c}3.23674 \mathrm{e}+06 \\
(0.210)\end{array}$ & $\begin{array}{c}0.07825^{\star *} \\
(0.021)\end{array}$ & $\begin{array}{c}0.05476 \\
(0.176)\end{array}$ \\
\hline $\begin{array}{c}\text { Lagged } \\
\text { Total Finish } 1\end{array}$ & $\begin{array}{c}3.46272 \mathrm{e}+06^{*} \\
(0.053)\end{array}$ & $\begin{array}{c}3.06418 \mathrm{e}+06^{*} \\
(0.096)\end{array}$ & $\begin{array}{c}0.06623^{\star *} \\
(0.033)\end{array}$ & $\begin{array}{c}0.06158^{\star \star} \\
(0.040)\end{array}$ \\
\hline Total Finish 2-5 & $\begin{array}{c}2.38724 \mathrm{e}+06^{* * *} \\
(0.002)\end{array}$ & $\begin{array}{c}1.80024 \mathrm{e}+06^{\star *} \\
(0.018)\end{array}$ & $\begin{array}{c}0.05617^{\star * \star} \\
(0.002)\end{array}$ & $\begin{array}{c}0.04933^{* *} \\
(0.015)\end{array}$ \\
\hline Total Finish 6-10 & $\begin{array}{c}1.08416 \mathrm{e}+06 \\
(0.123)\end{array}$ & $\begin{array}{c}1.10665 \mathrm{e}+06 \\
(0.112)\end{array}$ & $\begin{array}{c}0.07285^{\star \star *} \\
(0.000)\end{array}$ & $\begin{array}{c}0.07311^{* * *} \\
(0.000)\end{array}$ \\
\hline Other Finish & $\begin{array}{c}-1.34825 \mathrm{e}+05 \\
(0.629)\end{array}$ & $\begin{array}{c}-1.18185 \mathrm{e}+05 \\
(0.674)\end{array}$ & $\begin{array}{c}-0.00107 \\
(0.923)\end{array}$ & $\begin{array}{c}-0.00088 \\
(0.938)\end{array}$ \\
\hline Total DNF Non-Crash & $\begin{array}{c}-1.76995 \mathrm{e}+06 \\
(0.154)\end{array}$ & $\begin{array}{c}-1.66396 \mathrm{e}+06 \\
(0.170)\end{array}$ & $\begin{array}{c}-0.07585^{\star *} \\
(0.032)\end{array}$ & $\begin{array}{c}-0.07461^{* *} \\
(0.034)\end{array}$ \\
\hline Total DNF Crash & $\begin{array}{c}-57974.93517 \\
(0.954)\end{array}$ & $\begin{array}{c}22,274.07744 \\
(0.982)\end{array}$ & $\begin{array}{c}-0.00868 \\
(0.777)\end{array}$ & $\begin{array}{c}-0.00774 \\
(0.801)\end{array}$ \\
\hline Total Laps Led & & $\begin{array}{c}18,165.66113 \\
(0.117)\end{array}$ & & $\begin{array}{c}0.00021 \\
(0.289) \\
\end{array}$ \\
\hline Experience & $\begin{array}{c}2.57631 \mathrm{e}+06^{* * *} \\
(0.005)\end{array}$ & $\begin{array}{c}2.53411 \mathrm{e}+06^{* \star *} \\
(0.006)\end{array}$ & $\begin{array}{c}0.03608 \\
(0.169) \\
\end{array}$ & $\begin{array}{c}0.03559 \\
(0.177) \\
\end{array}$ \\
\hline Experience Squared & $\begin{array}{c}-1.02496 \mathrm{e}+05^{\star * *} \\
(0.000)\end{array}$ & $\begin{array}{c}-1.00605 \mathrm{e}+05^{\star \star *} \\
(0.001)\end{array}$ & $\begin{array}{c}-0.00179^{* *} \\
(0.040)\end{array}$ & $\begin{array}{c}-0.00177^{\star *} \\
(0.044)\end{array}$ \\
\hline Son & $\begin{array}{c}3.94447 e+07^{* * *} \\
(0.000)\end{array}$ & $\begin{array}{c}3.94743 e+07^{* * *} \\
(0.000)\end{array}$ & $\begin{array}{c}0.70731^{* * *} \\
(0.000)\end{array}$ & $\begin{array}{c}0.70765^{\star * *} \\
(0.000)\end{array}$ \\
\hline Brother & $\begin{array}{c}4.44261 \mathrm{e}+06 \\
(0.332)\end{array}$ & $\begin{array}{c}4.57339 e+06 \\
-0.314 \\
\end{array}$ & $\begin{array}{c}0.07257 \\
(0.599) \\
\end{array}$ & $\begin{array}{c}0.07409 \\
(0.591) \\
\end{array}$ \\
\hline Year Fixed Effects & Yes & Yes & Yes & Yes \\
\hline Constant & $\begin{array}{c}6.65091 \mathrm{e}+06 \\
(0.560)\end{array}$ & $\begin{array}{c}5.72516 \mathrm{e}+06 \\
(0.616)\end{array}$ & $\begin{array}{c}16.36431^{* * *} \\
(0.000)\end{array}$ & $\begin{array}{c}16.35351^{* * *} \\
(0.000)\end{array}$ \\
\hline H0: Homoscedasticity & $49.07^{\star \star \star}$ & $48.29^{\star \star \star}$ & $18.94^{\star \star \star}$ & $20.09^{\star \star \star}$ \\
\hline Observations & 214 & 214 & 214 & 214 \\
\hline R-squared & 0.594 & 0.601 & 0.550 & 0.552 \\
\hline \multicolumn{5}{|c|}{$\begin{array}{l}\text { Robust pval in parentheses. Test for heteroscedasticity is a Cook-Weisberg test } \\
\text { distributed Chi-squared with one degree of freedom. }\end{array}$} \\
\hline & ${ }^{* \star *} p<0.01,{ }^{*}$ & $p<0.05,{ }^{*} p<0.1$ & & \\
\hline
\end{tabular}


Table 5: Determinants of Value of Time on Camera with Specific Son Controls

\begin{tabular}{|c|c|c|c|c|}
\hline VARIABLES & $\begin{array}{l}\text { Model 9: } \\
\text { LnValue }\end{array}$ & $\begin{array}{l}\text { Model 10: } \\
\text { LnValue }\end{array}$ & $\begin{array}{l}\text { Model 11: } \\
\text { LnValue }\end{array}$ & $\begin{array}{l}\text { Model 12: } \\
\text { LnValue }\end{array}$ \\
\hline Total Finish 1 & $\begin{array}{c}0.09740^{* * *} \\
(0.001)\end{array}$ & $\begin{array}{c}0.06828^{*} \\
(0.051)\end{array}$ & $\begin{array}{c}0.06353^{* *} \\
(0.047)\end{array}$ & $\begin{array}{c}0.05761 \\
(0.113) \\
\end{array}$ \\
\hline $\begin{array}{c}\text { Lagged } \\
\text { Total Finish } 1\end{array}$ & & & $\begin{array}{c}0.06226^{\star \star} \\
(0.033)\end{array}$ & $\begin{array}{c}0.06117^{\star \star} \\
(0.034)\end{array}$ \\
\hline Total Finish 2-5 & $\begin{array}{c}0.08631^{* * *} \\
(0.000)\end{array}$ & $\begin{array}{c}0.07918^{* * *} \\
(0.000)\end{array}$ & $\begin{array}{c}0.05534^{* * *} \\
(0.001)\end{array}$ & $\begin{array}{c}0.05355^{\star * *} \\
(0.004)\end{array}$ \\
\hline Total Finish 6-10 & $\begin{array}{c}0.09059^{* * *} \\
(0.000)\end{array}$ & $\begin{array}{c}0.08929^{* * *} \\
(0.000)\end{array}$ & $\begin{array}{c}0.06057^{* * *} \\
(0.000)\end{array}$ & $\begin{array}{c}0.06070^{* * *} \\
(0.000)\end{array}$ \\
\hline Total Finish Other & $\begin{array}{c}0.02159^{*} \\
(0.059)\end{array}$ & $\begin{array}{c}0.02174^{*} \\
(0.058)\end{array}$ & $\begin{array}{c}-0.00158 \\
(0.885)\end{array}$ & $\begin{array}{c}-0.00157 \\
(0.886)\end{array}$ \\
\hline Total DNF Non-Crash & $\begin{array}{c}-0.05722^{* \star} \\
(0.026)\end{array}$ & $\begin{array}{c}-0.05843^{\star *} \\
(0.022)\end{array}$ & $\begin{array}{c}-0.05160^{*} \\
(0.095)\end{array}$ & $\begin{array}{c}-0.05144^{*} \\
(0.097)\end{array}$ \\
\hline Total DNF Crash & $\begin{array}{c}0.00193 \\
(0.953) \\
\end{array}$ & $\begin{array}{c}0.00075 \\
(0.982) \\
\end{array}$ & $\begin{array}{c}-0.04147 \\
(0.151) \\
\end{array}$ & $\begin{array}{c}-0.04135 \\
(0.154) \\
\end{array}$ \\
\hline Total Laps Led & & $\begin{array}{c}0.00024 \\
(0.155) \\
\end{array}$ & & $\begin{array}{c}0.00005 \\
(0.732) \\
\end{array}$ \\
\hline Experience & $\begin{array}{c}0.02112 \\
(0.461) \\
\end{array}$ & $\begin{array}{c}0.01875 \\
(0.520) \\
\end{array}$ & $\begin{array}{c}0.01763 \\
(0.554) \\
\end{array}$ & $\begin{array}{c}0.01689 \\
(0.579) \\
\end{array}$ \\
\hline Experience Squared & $\begin{array}{c}-0.00122 \\
(0.206) \\
\end{array}$ & $\begin{array}{c}-0.00113 \\
(0.252) \\
\end{array}$ & $\begin{array}{c}-0.00132 \\
(0.225) \\
\end{array}$ & $\begin{array}{c}-0.00129 \\
(0.246) \\
\end{array}$ \\
\hline Bobby Hamilton Jr. & $\begin{array}{c}-0.00630 \\
(0.966) \\
\end{array}$ & $\begin{array}{c}-0.00112 \\
(0.994) \\
\end{array}$ & & \\
\hline Chad Little & $\begin{array}{c}-0.03378 \\
(0.862)\end{array}$ & $\begin{array}{c}-0.02790 \\
(0.886)\end{array}$ & & \\
\hline Dale Earnhardt Jr & $\begin{array}{c}1.36889^{* * *} \\
(0.000)\end{array}$ & $\begin{array}{c}1.33976^{* * *} \\
(0.000)\end{array}$ & $\begin{array}{c}1.26085^{\star \star *} \\
(0.000)\end{array}$ & $\begin{array}{c}1.25503^{* * *} \\
(0.000)\end{array}$ \\
\hline Dale Jarrett & $\begin{array}{c}0.77870^{* *} \\
(0.011)\end{array}$ & $\begin{array}{c}0.82630^{* * *} \\
(0.005)\end{array}$ & $\begin{array}{c}1.01201^{* * *} \\
(0.000)\end{array}$ & $\begin{array}{c}1.02097^{* * *} \\
(0.000)\end{array}$ \\
\hline Johnny Benson Jr. & $\begin{array}{c}0.64016^{* *} \\
(0.023)\end{array}$ & $\begin{array}{c}0.66674^{* *} \\
(0.018)\end{array}$ & $\begin{array}{c}0.40037^{* *} \\
(0.013)\end{array}$ & $\begin{array}{c}0.40450^{* *} \\
(0.013)\end{array}$ \\
\hline Kyle Petty & $\begin{array}{c}-0.08790 \\
(0.758)\end{array}$ & $\begin{array}{c}-0.09484 \\
(0.741)\end{array}$ & $\begin{array}{c}-0.03223 \\
(0.912)\end{array}$ & $\begin{array}{c}-0.03395 \\
(0.908)\end{array}$ \\
\hline Larry Foyt & $\begin{array}{c}-0.84206^{* * *} \\
(0.008)\end{array}$ & $\begin{array}{c}-0.84687^{* * *} \\
(0.008)\end{array}$ & & \\
\hline Sterling Marlin & $\begin{array}{c}0.42979 \\
(0.112)\end{array}$ & $\begin{array}{c}0.41739 \\
(0.125)\end{array}$ & $\begin{array}{c}0.60407^{* *} \\
(0.032)\end{array}$ & $\begin{array}{c}0.59938^{* *} \\
(0.036)\end{array}$ \\
\hline Year Fixed Effects & Yes & Yes & Yes & Yes \\
\hline Brother Fixed Effects & Yes & Yes & Yes & Yes \\
\hline Constant & $\begin{array}{c}15.04433^{\star \star \star} \\
(0.000)\end{array}$ & $\begin{array}{c}15.05295^{\star \star *} \\
(0.000)\end{array}$ & $\begin{array}{c}16.58059^{* * *} \\
(0.000)\end{array}$ & $\begin{array}{c}16.58232^{* \star *} \\
(0.000)\end{array}$ \\
\hline \multicolumn{5}{|l|}{ H0: Homoscedasticity } \\
\hline Observations & 304 & 304 & 214 & 214 \\
\hline R-squared & 0.620 & 0.622 & 0.710 & 0.711 \\
\hline Robust pval in paren & $\begin{array}{l}\text { es. Test for } h \\
\text { Chi-squared } \\
{ }^{\star \star \star} p<0.01,{ }^{\star \star}\end{array}$ & $\begin{array}{l}\text { eroscedastic } \\
\text { th one degre } \\
0<0.05,{ }^{*} p<0\end{array}$ & $\begin{array}{l}y \text { is a Cook-V } \\
\text { of freedom. }\end{array}$ & isberg test \\
\hline
\end{tabular}


Table 6: Determinants of Value of Time on Camera with Fixed Effect Panel

\begin{tabular}{|c|c|c|}
\hline VARIABLES & $\begin{array}{l}\text { Model } 12 \\
\text { LnValue }\end{array}$ & $\begin{array}{l}\text { Model } 13 \\
\text { LnValue }\end{array}$ \\
\hline Total Finish 1 & $\begin{array}{c}0.06865^{\star} \\
(0.066)\end{array}$ & $\begin{array}{c}0.02835 \\
(0.493)\end{array}$ \\
\hline Total Finish 2-5 & $\begin{array}{c}0.06819^{\star * *} \\
(0.001)\end{array}$ & $\begin{array}{c}0.05875^{\star \star \star} \\
(0.005)\end{array}$ \\
\hline Total Finish 6-10 & $\begin{array}{c}0.06925^{\star * *} \\
(0.000)\end{array}$ & $\begin{array}{c}0.06720^{\star \star \star} \\
(0.000)\end{array}$ \\
\hline Other Finish & $\begin{array}{c}0.01963 \\
(0.118)\end{array}$ & $\begin{array}{c}0.01947 \\
(0.119) \\
\end{array}$ \\
\hline Total DNF Non-Crash & $\begin{array}{c}-0.05958^{* *} \\
(0.042)\end{array}$ & $\begin{array}{c}-0.06138^{* *} \\
(0.031)\end{array}$ \\
\hline Total DNF Crash & $\begin{array}{c}-0.05993^{*} \\
(0.056)\end{array}$ & $\begin{array}{c}-0.05892^{*} \\
(0.064)\end{array}$ \\
\hline Total Laps Led & & $\begin{array}{c}0.00035^{\star} \\
(0.051)\end{array}$ \\
\hline Experience & $\begin{array}{c}-0.01093 \\
(0.830) \\
\end{array}$ & $\begin{array}{c}-0.01357 \\
(0.791) \\
\end{array}$ \\
\hline Experience Squared & $\begin{array}{c}-0.00175^{*} \\
(0.094)\end{array}$ & $\begin{array}{c}-0.00167 \\
(0.113) \\
\end{array}$ \\
\hline Year Fixed Effects & Yes & Yes \\
\hline Constant & $\begin{array}{c}15.82571^{* * *} \\
(0.000)\end{array}$ & $\begin{array}{c}15.83526^{* * *} \\
(0.000)\end{array}$ \\
\hline Observations & 304 & 304 \\
\hline Number of Drivers & 77 & 77 \\
\hline R-squared: Within & 0.338 & 0.343 \\
\hline R-squared: Between & 0.314 & 0.318 \\
\hline R-squared: Overall & 0.341 & 0.347 \\
\hline \multicolumn{3}{|c|}{ Robust pval in parentheses. } \\
\hline
\end{tabular}


Sponsorship Contracts for Various Sports Stars

\begin{tabular}{|c|c|c|c|c|c|c|c|c|}
\hline Last & First & Sport & 2012 & 2011 & 2010 & 2009 & 2008 & 2007 \\
\hline Mickelson & Phil & Golf & $57,000,000$ & $57,000,000$ & $52,000,000$ & $46,600,000$ & $53,000,000$ & $47,000,000$ \\
\hline Woods & Tiger & Golf & $54,000,000$ & $60,000,000$ & $70,000,000$ & $92,000,000$ & $105,000,000$ & $100,000,000$ \\
\hline James & LeBron & NBA & $33,000,000$ & $30,000,000$ & $30,000,000$ & $28,000,000$ & $28,000,000$ & $25,000,000$ \\
\hline Bryant & Kobe & NBA & $28,000,000$ & $10,000,000$ & $10,000,000$ & $10,000,000$ & $16,000,000$ & $16,000,000$ \\
\hline Earnhardt Jr & Dale & NASCAR & $24,000,000$ & $22,000,000$ & $22,000,000$ & $22,000,000$ & $22,000,000$ & $20,000,000$ \\
\hline Rose & Derrick & NBA & $18,230,770$ & & & & & \\
\hline Gordon & Jeff & NASCAR & $18,000,000$ & $18,000,000$ & $15,000,000$ & $15,000,000$ & $15,000,000$ & $15,000,000$ \\
\hline Stewart & Tony & NASCAR & $15,470,000$ & & & & & \\
\hline Johnson & Jimmie & NASCAR & $14,730,640$ & $12,000,000$ & $10,000,000$ & & $3,000,000$ & $2,000,000$ \\
\hline Manning & Peyton & NFL & $13,000,000$ & $15,000,000$ & $15,000,000$ & $13,000,000$ & $13,000,000$ & $13,000,000$ \\
\hline Durant & Kevin & NBA & $12,482,840$ & $14,000,000$ & & & $21,650,000$ & \\
\hline Jeter & Derek & MLB & $12,000,000$ & $10,000,000$ & $10,000,000$ & $8,500,000$ & $8,000,000$ & $7,000,000$ \\
\hline Wade & Dwyane & $\mathrm{NBA}$ & $12,000,000$ & $14,000,000$ & $12,000,000$ & $12,000,000$ & $12,000,000$ & $12,000,000$ \\
\hline Howard & Dwight & NBA & $11,000,000$ & $12,000,000$ & $12,000,000$ & $12,000,000$ & $15,500,000$ & \\
\hline Anthony & Carmelo & $\mathrm{NBA}$ & $10,000,000$ & & & & & \\
\hline Brady & Tom & NFL & $10,000,000$ & $10,000,000$ & $10,000,000$ & $10,000,000$ & $10,000,000$ & $9,000,000$ \\
\hline Manning & Eli & NFL & $10,000,000$ & & & & & \\
\hline Garnett & Kevin & $\mathrm{NBA}$ & $5,000,000$ & $14,000,000$ & $10,000,000$ & $10,000,000$ & & $8,000,000$ \\
\hline Wie & Michelle & Golf & & & & & & $19,500,000$ \\
\hline O'Neal & Shaquille & NBA & & & $15,000,000$ & $15,000,000$ & $15,000,000$ & $15,000,000$ \\
\hline Furyk & Jim & Golf & & & & $11,000,000$ & $11,000,000$ & \\
\hline
\end{tabular}

Source: http://sportsillustrated.cnn.com/more/specials/fortunate50/2007/index.html http://sportsillustrated.cnn.com/more/specials/fortunate50/2008/index.html http://sportsillustrated.cnn.com/more/specials/fortunate50/2009/index.html http://sportsillustrated.cnn.com/specials/fortunate50-2010/index.html http://sportsillustrated.cnn.com/specials/fortunate50-2011/index.html http://sportsillustrated.cnn.com/specials/fortunate50-2012/index.html 


\section{References}

Adler, M. (1985). "Stardom and Talent” American Economic Review, 75(1), 208-12.

Amato, C, C. L. Peters and A. Shao (2005). "An Exploratory Investigation into NASCAR Fan Culture” Sports Marketing Quarterly, 14(2), 71-83.

Breuer, Christoph and Christopher Rumpf (2012). "The Viewer's Reception and Processing of Sponsorship Information in Sport Telecasts" Journal of Sport Management 26, 521-531

Brown, Z. (2008). "Wind Tunnel with Dave Despain" Interview Speed Channel, March 30 .

Cornwell, T. B., S. W. Pruitt, and J. M. Clark (2005). “The Relationship Between Majorleague Sports' OfficialSponsorship Announcements and the Stock Prices of Sponsoring Firms" Journal of the Academy of Marketing Science, 33(4), 401-412.

Durr, D., D.H. Eaton and T. Broker (2009). "Outracing the Market: A NASCAR Portfolio Test Case of Returns and Diversification” Journal of Applied Economics and Policy, 28(1), 57-68.

Franck, E. and S. Nüesch (2010). "Talent and/or Popularity: What does it take to be a Superstar?" Forthcoming in Economic Inquiry

Gage, J. (2006). "The big money of motorsports" Forbes.com, 18 May, www.msnbc.msn.com/id/12861186/, last accessed June 2011.

Groothuis, P. and J. Groothuis (2008). "Nepotism in NASCAR" Journal of Sports Economics, 9(3), 250-265.

Gwinner, K. and J. Eaton (1999). "Building Brand Image through Event Sponsorship: The Role of Image Transfer" Journal of Advertising, 28(4), 47-57.

Hamlen, W. (1991). "Superstardom in Popular Music: Empirical Evidence" Review of Economics and Statistics, 73(4), 729-33.

Hamlen, W. (1994). "Variety in Superstardom in Popular Music" Economic Inquiry, 32(3), 395-406.

Hood, M., E. King, and C. Depken (2012) "Consistency and Momentum in NASCAR: Obtainable? Desirable?" mimeo, Texas State University.

Knittel, C. R. and V. Stango (2010). "Celebrity Endorsements, Firm Value and Reputation Risk: Evidence from the Tiger Woods Scandal" mimeo, UC Davis (Dated August 25, 2010, accessed October 8, 2010). 
Krueger, A. B. (2005). “The Economics of Real Superstars: The Market for Concerts in the Material World" Journal of Labor Economics, 23(1), 1-30.

Laband, D. N. and B. F. Lentz (1983). "Like Father, Like Son: Toward an Economic Theory of Occupational Following” Southern Economic Journal, 50(2), 474-493.

Laband, D. N. and B. F. Lentz (1985). "Favorite Sons: Intergenerational Wealth Transfers Among Politicians" Economic Inquiry, 23(3), 394-414.

Laband, D. N. and B. F. Lentz (1990a). "Entrepreneurial Success and Occupational Inheritance among Proprietors" The Canadian Journal of Economics, 23(3), 563579.

Laband, D. N. and B. F. Lentz (1990b). "Family Tradition in Professional Baseball: An Economic Interpretation” Sportometrics, TexasA\&M University Press.

Lou, L., Chen, X., Han J., and Park C. (2010) "Dilution and Enhancement of Celebrity Brands through Sequential Movie Releases" Journal of Marketing Research, 47(6).

Mahar, J., R. Paul and L. Stone (2005). "An Examination of Stock Market Response to NASCAR Race Performance” Marketing Management Journal, 15(2), 80-86.

McGee, R. (2005). "NASCAR Nation's Big Story: The Cost of Racing” Fox Sports.

Meenaghan, T (1991). "The Role of Sponsorship in Marketing Communications Mix" International Journal of Advertising, 10(2), 35-47.

Pruitt, S. W., T. B. Cornwell, and J. M. Clark (2004). "The NASCAR Phenomenon: Auto Racing Sponsorship and Shareholder Wealth" Journal of Advertising Research, 44(3), 281-297.

Rosen, S. (1981). "The Economics of Superstars" American Economic Review, 71(5), 845-58.

Sirgy, M. Joseph, Dong-Jin Lee, J. S. Johar, and John Tidwell (2008) “Effect of SelfCongruity with Sponsorship on Brand Loyalty" Journal of Business Research, 61(10), 1091-1097 